\title{
Peningkatan Keterampilan Produksi VCO pada UMKM "Bay Tat Mak Ririn" melalui Pemanfaatan Limbah Selai Nanas
}

Gustria Ernis ${ }^{1}$, Apriza Hongko Putra ${ }^{2}$, Refpo Rahman ${ }^{3}$

${ }^{123}$ Program Studi D-III Laboratorium Sains, Fakultas MIPA, Universitas Bengkulu Email: gustriaernis@unib.ac.id

\begin{tabular}{ll}
\hline Article History: & Abstrak: \\
Received: Desember & Virgin Coconut Oil (VCO) merupakan \\
2020 & salah satu alternatif imunostimulan alami \\
Revised:Juni 2021 & yang dapat meningkatkan daya tahan \\
Accepted: Juni 2021 & tubuh di tengah pandemi COVID-19. \\
Available online: Juni & Salah satu enzim yang digunakan dalam \\
2021 & pembuatan VCO adalah enzim bromelin. \\
& Limbah pengolahan selai nanas berupa \\
& kulit dan mata nanas mengandung enzim \\
Kata Kunci: & bromelin yang dapat mempercepat \\
enzim bromelin, & terbentuknya VCO. Metode pengabdian \\
imunostimulan, limbah & ini adalah dengan memberikan sosialisasi \\
selai nanas, & dan pelatihan pembuatan VCO kepada \\
peningkatan produksi & anggota UMKM Bay Tat Mak Ririn. \\
VCO, virgin coconut & Setelah dilakukan pelatihan, anggota \\
oil (VCO) & UMKM Bay Tat Mak Ririn berhasil \\
& memproduksi VCO melalui pemanfaatan \\
& limbah selai nanas. Disamping itu, \\
& diperoleh peningkatan produksi VCO \\
& menggunakan enzim bromelin yang \\
& bersumber dari limbah selai nanas sebesar \\
& $1,8 \%$ dibandingkan dengan VCO tanpa \\
enzim bromelin. Hal ini menunjukkan \\
& bahwa keterampilan peserta dalam \\
& memproduksi VCO melalui pemanfaatan \\
& limbah selai nanas meningkat.
\end{tabular}




\section{Pendahuluan}

Merebaknya virus corona membuat kesadaran masyarakat akan daya tahan tubuh dan hidup sehat meningkat. Cara yang paling mendasar dalam mencegah bahkan menangkal virus covid-19 ini adalah dengan meningkatkan daya tahan tubuh atau sistem imun. Sehingga masyarakat banyak memburu produk imunostimulan yang ada di pasaran meskipun dengan harga yang melonjak tinggi dan menyebabkan kelangkaan produk. Minyak kelapa murni atau virgin coconut oil (VCO) merupakan salah satu imunostimulan dengan kandungan asam laurat yang tinggi. Asam laurat didalam tubuh akan diubah menjadi monolaurin yaitu sebuah senyawa monogliserida yang bersifat antivirus, antibakteri, antiprotozoa, sehingga dapat meningkatkan daya tahan tubuh manusia terhadap penyakit serta mempercepat proses penyembuhan. Beberapa penelitian in vitro, hewan, dan manusia mendukung potensi minyak kelapa (VCO), asam laurat dan turunannya sebagai agen yang efektif dan aman terhadap virus seperti nCoV-2019 (Dayrit \& Newport, 2020). Selain itu, manfaat lain dari VCO yang telah dilaporkan diantaranya adalah sebagai antibakteri (Noriko, Masduki, Azhari, \& Nufadianti, 2014), antioksidan (Ghani et al., 2018), antiprotozoa (Karouw, Indrawanto, \& Kapu'allo, 2014), Penurunan resiko cardiovascular (Babu, Veluswamy, Arena, Guazzi, \& Lavie, 2014), dan masih banyak lagi manfaat lainnya.

Melimpahnya ketersediaan bahan baku VCO, yaitu kelapa dapat dilihat dari total luas areal perkebunan kelapa di Indonesia yang mencapai 3.712 juta hektar $(31,4 \%)$ dan merupakan luas areal perkebunan kelapa terbesar di dunia. Dikalangan masyarakat, masih banyak yang belum memahami cara pembuatan VCO dengan teknik enzimatis. Kebanyakan masyarakat membuat VCO dengan cara tradisional, dengan mendiamkan cairan santan dan membutuhkan waktu yang lama. VCO dapat diproduksi menggunakan enzimatis, pemancingan (Oseni, Fernando, Coorey, Gold, \& Jayasena, 2017), sentrifugasi, fermentasi alami dan proses fermentasi yang diinduksi (Karouw et al., 2014), Kombinasi metode enzimatik dengan teknik fermentasi (Prayitno, 2014). Metode enzimatik dapat dilakukan karena adanya enzim proteolitik. Enzim proteolitik dapat mempercepat reaksi hidrolisis dari protein sehingga dapat menghemat waktu. Salah satu enzim proteolitik adalah 
enzim bromelin.

Tanpa disadari, limbah yang ada di sekitar kita khusunya limbah pengolahan selai nanas yang merupakan produk andalan di industri makanan khas Bengkulu mengandung enzim bromelin. Enzim bromelin dapat diperoleh pada batang, buah, mahkota, bunga, inti dan kulit nanas (Wiyati \& Tjitraresmi, 2015). Salah satu industri makanan khas Bengkulu yang mengolah sendiri selai nanas sebagai toping utama kue tat dan mengeluhkan kesulitan akibat dampak Covid-19 ini adalah UMKM Bay Tat Mak Ririn yang berdiri sejak tahun 2000 yang beralamat di Kelurahan Kebun Kenanga, Kecamatan Ratu Agung, Kota Bengkulu. UMKM Bay Tat Mak Ririn mengalami penurunan pendapatan sekitar 40-60\% diakibatkan dampak Covid-19 ini. Diketahui, kue tat merupakan makanan khas Bengkulu yang biasanya dijadikan oleh-oleh bagi wisatawan yang datang ke Bengkulu maupun warga Bengkulu yang bepergian. Sehingga dengan adanya pembatasan wilayah berskala besar akibat Covid-19 mengakibatkan penjualan Bay Tat Mak Ririn menurun drastis. Padahal pekerja pada UMKM ini pada umunya adalah ibu-ibu rumah tangga yang bergantung untuk memenuhi kebutuhan keluarganya.

Saat ini, usaha Bay Tat Mak Ririn mampu mengolah 150 buah nanas/bulan yang kemudian diolah menjadi selai nanas sebanyak $30 \mathrm{~kg}$. Dalam pengolahan selai nanas ini, bagian yang digunakan hanyalah buah nanasnya saja, sedangkan bagian mata nanas, kulit dan batang hanya dibuang begitu saja sebagai limbah (Gambar 2). Untuk mencegah terjadinya pemutusan hubungan kerja (PHK) di UMKM Bay Tat Mak Ririn, sangat dibutuhkan pembinaan untuk memanfaatkan limbah yang dihasilkan sebagai sumber enzim bromelin dalam mempercepat pembuatan VCO yang bernilai guna bahkan bernilai ekonomi.

Adapun tujuan kegiatan pengabdian ini adalah meningkatkan pengetahuan dan keterampilan kelompok sasaran dalam memanfaatkan limbah selai nanas pada pembuatan VCO untuk imunostimulan sebagai pencegahan terhadap Covid19. 


\section{Metode}

Metode yang dilakukan pada pengabdian ini adalah sosialisasi (ceramah), pelatihan (demonstrasi dan praktek). Hal ini dipilih karena metode tersebut dinilai efektif dalam program pengabdian dengan hasil akhir berupa produk, hal ini dilihat dari tingkat keberhasilan masyarakat dalam menciptakan produk yang dimaksud dalam kegiatan (Triawan, Banon, \& Adfa, 2019). Uraian metode kegiatan pengabdian tersebut dapat dilihat sebagai berikut:

\section{Sosialisasi}

Kegiatan yang dilakukan pada tahapan ini adalah: persiapan masyarakat peserta penyuluhan, persiapan peralatan dan perlengkapan, dan persiapan bahan presentasi. Pada tahap pelaksanaan sosialisasi, materi yang disampaikan berupa pengenalan sumber imunostimulan di sekitar kita (khususnya limbah pengolahan selai nanas) untuk dijadikan sumber enzim bromelin guna mempercepat proses pembuatan VCO. Disampaikan manfaat dan keuntungan VCO dalam mencegah dan menangkal virus corona. Dilakukan juga diskusi tentang materi yang disampaikan. Pada akhir pertemuan, masyarakat diberikan video simulasi pembuatan VCO dengan memanfaatkan limbah selai nanas dan dibagikan juga print out cara pembuatan VCO, dan masyarakat diberi pertanyaan-pertanyaan tentang pembuatan VCO hingga dirasa sudah paham.

\section{Pelatihan}

Alat yang diperlukan dalam pembuatan VCO terdiri dari baskom, saringan, toples dengan keran dibagian bawah, blender dan pisau. Sedangkan bahan yang diperlukan adalah buah kelapa segar, air, limbah pengolahan selai nanas. Untuk pembuatan enzim bromelin segar, limbah pengolahan selai nanas segar (kulit, mata, bonggol, dll) dihaluskan menggunakan blender, kemudian didiamkan sekitar 1 jam hingga ampas dan sari buah nanas terpisah. Kemudian sari buah nanas diambil untuk dijadikan enzim bromelin segar. Disediakan santan kental dan didiamkan hingga krim dan air santan terpisah. Kemudian diambil bagian krim santan, dan dimasukkan ke dalam toples dengan keran di bagian bawah. Krim santan di campurkan dengan enzim 
bromelin segar (Diaduk). Didiamkan hingga terbentuk minyak (24 Jam). Pengambilan VCO dapat dilakukan dengan membuka keran toples secara perlahan. Untuk lebih jelasnya, dapat dilihat dari langkah-langkah berikut ini:

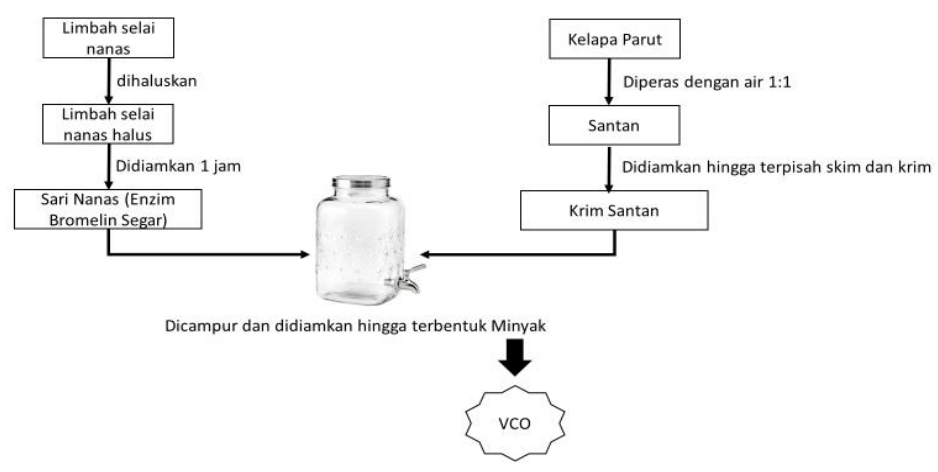

Gambar 1. Langkah-langkah pembuatan VCO

\section{Hasil}

Pelaksanaan kegiatan pengabdian ini dilakukan di rumah ketua UMKM "Bay Tat Mak Ririn" di Kelurahan Kebun Kenanga, Kecamatan Ratu Agung, Kota Bengkulu yang dihadiri oleh seluruh anggota UMKM "Bay Tat Mak Ririn". Hasil sosialisasi dan pelatihan dapat dilihat dari uraian berikut ini:

1. Sosialisasi

Pada tahapan pengabdian ini dilakukan sosialisasi mengenai sumber imunostimulan alami, salah satunya adalah VCO. Penjelasan ini dilakukan oleh anggota pengabdian, yaitu Bapak Apriza Hongko Putra. Selain menjelaskan sumber imunostimulan, dijelaskan juga mengenai enzim bromelin yang terdapat di dalam buah nanas, bahkan dikulitnya yang hanya dijadikan limbah. Tentang berbagai macam manfaat VCO serta harga VCO di pasaran dijelaskan oleh anggota pengabdian yang yaitu Bapak Refpo Rahman. Sangat banyak sekali manfaat dari VCO untuk kesehatan, salah satunya untuk imunostimulan yang dapat meningkatkan daya tahan tubuh. Selain itu VCO juga sangat bermanfaat bagi kesehatan kulit dan rambut. Dilihat dari berbagai situs marketplace seperti tokopedia, shopee, marketplace facebook, dll rata-rata harga VCO adalah Rp.30.000/ 100 mL. 
Dharma Raflesia

Jurnal Ilmiah Pengembangan dan Penerapan IPTEKS

Vol. 19, No. 01, Juni, 2021, pp. 71 - 81

Sehingga peserta sangat antusias dalam mengikuti penjelasan dari tim pengabdian dan tidak sabar untuk segera mengikuti pelatihan pembuatan VCO.

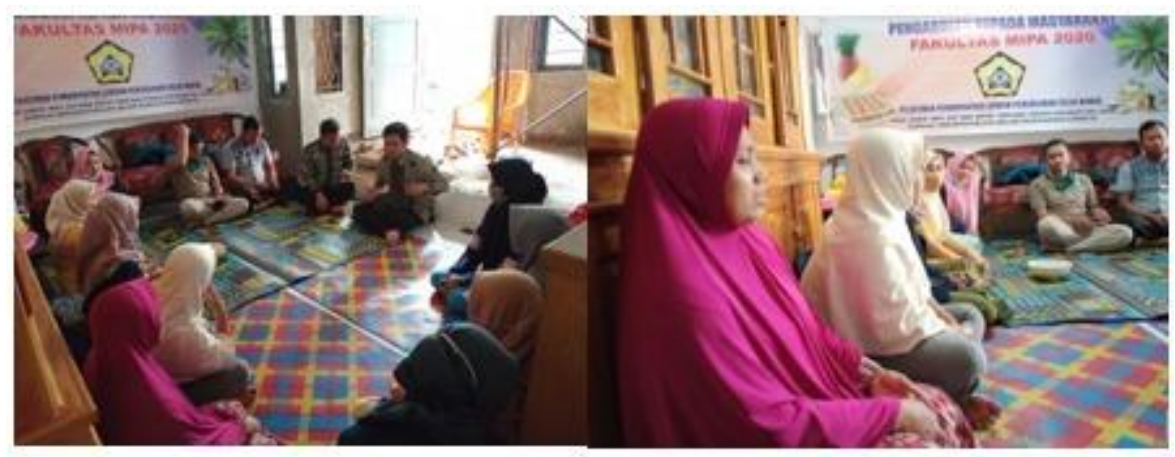

Gambar 2. Kegiatan sosialisasi sumber imunostimulan

\section{Pelatihan}

Pada kegiatan pelatihan ini dipandu oleh ketua tim pengabdian, yaitu ibu Gustria Ernis yang melibatkan mahasiswa dan peserta dari UMKM dalam mempraktekkannya. Sebelumnya sumber enzim bromelin telah disiapkan oleh UMKM Bay Tat Mak Ririn sebagai limbah dari pembuatan selai nanas. Sedangkan santan dan peralatan lainnya disiapkan oleh tim pengabdi. Untuk pembuatan VCO kita gunakan krim santan saja. Kulit nanas dihaluskan dengan blender dan diambil sari nya sebagai sumber enzim bromelin, dicampurkan ke krim santan sebanyak 50\% dan dilakukan pengadukan, hal ini dilakukan langsung oleh mahasiswa dan peserta pelatihan dari UMKM (Gambar 3).

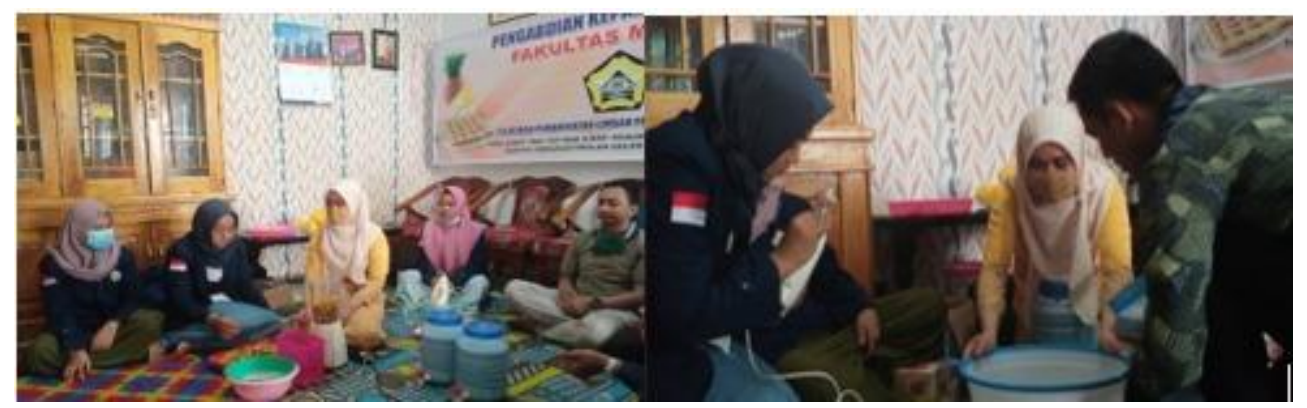

Gambar 3. Kegiatan Pelatihan Pembuatan VCO 
Setelah dilakukan mengadukan, santan didiamkan dalam suasana gelap (di dalam lemari) selama 24 jam. Pada pelatihan hari ke dua, diperoleh santan yang sudah berpisah menjadi 3 lapisan, yaitu lapisan air pada bagian bawah, lapisan minyak (VCO) dibagian tengah, dan lapisan protein (blondo) pada bagian atas (Gambar 4).
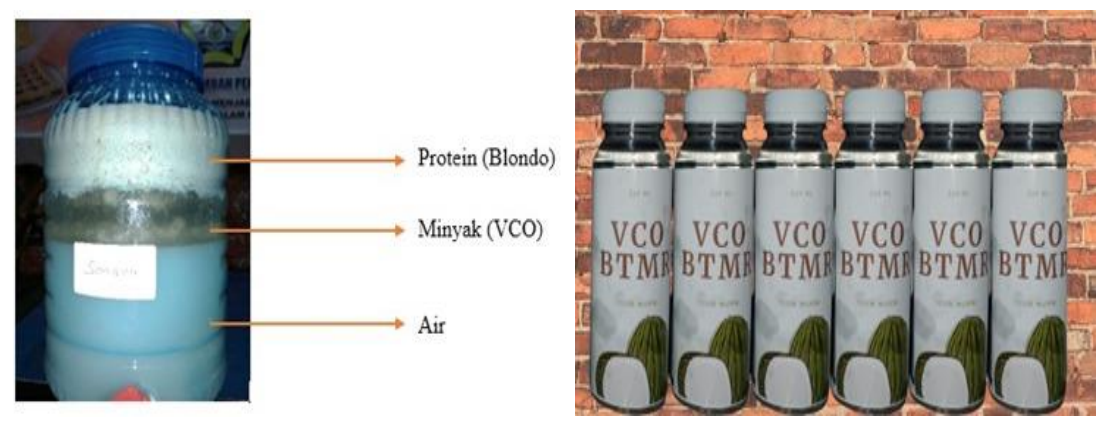

Gambar 4. Hasil pembuatan VCO

Dari hasil pelatihan, masyarakat dapat memproduksi VCO dari santan dengan bantuan enzim bromelin yang berasal dari limbah selai nanas dengan cara membuka kran hingga lapisan air habis, sehingga minyak bisa diambil. VCO yang dihasilkan memiliki bau yang khas, bau minyak kelapa murni dan jernih serta enak jika diminum. Dari $5 \mathrm{Kg}$ santan, diperoleh $500 \mathrm{~mL}$ VCO (Rendemen sebesar 10\%). masyarakat sangat antusias untuk melanjutkan pembuatan VCO kedepannya, baik untuk kebutuhan pribadi, maupun untuk diperjual-belikan. Kemasan VCO juga telah dibuat dengan merek VCO BTMR (Bay Tat Mak Ririn) yang dapat dilihat dari Gambar 4.

\section{Diskusi}

Dari kegiatan sosialisasi pengabdian ini diketahui bahwa pengetahuan masyarakat dalam membuat virgin coconut oil (VCO) masih secara konvensional, yaitu dengan cara memasak hingga muncul minyak kelapa. Dari hasil wawancara sebelum kegiatan pengabdian ini, anggota UMKM "Bay Tat Mak Ririn" juga belum mengetahui segudang manfaat berharga dari VCO. Hal ini juga sejalan dengan hasil pengabdian yang dilakukan pada ibu-ibu warga RT 12 Kelurahan Pematang Gubernur,Kecamatan Muara Bangkahulu, Kota Bengkulu yang diketahui juga belum memahami berbagai manfaat yang 
sangat baik dari VCO bagi kesehatan (Sutanto, Martono, \& Ratnawati, 2017).

Dengan adanya sosialisasi ini, peserta dapat mengetahui berbagai metode dalam pembuatan VCO, salah satunya metode enzimatis. Peserta baru mengetahui bahwa kulit nanas dapat dimanfaatkan menjadi hal yang berguna, sehingga peserta sangat antusias untuk mengikuti pelatihan pembuatan VCO. Antusiasme peserta ini dapat terlihat dari banyaknya pertanyaan dan tanggapan terhadap materi yang diberikan pada sesi diskusi. Hal ini dikarenakan masyarakat sasaran (Anggota UMKM Bay Tat Mak Ririn) merasa mendapatkan ilmu baru yang sangat berguna dan tepat sasaran dengan memanfaatkan limbah yang sering mereka hasilkan.

Pada kegiatan pelatihan, santan disiapkan dari kelapa tua yang dipesan langsung pada pengusaha santan di pasar pematang gubernur tanpa penambahan air, sehingga bisa langsung diolah menjadi VCO. Jika digunakan santan yang diperas dari kelapa parut, maka harus didiamkan sekitar 1-2 jam terlebih dahulu agar air dan krim santannya berpisah. Kegiatan pelatihan ini dilakukan langsung oleh mahasiswa dan peserta.

Produksi VCO menggunakan enzim bromelin yang bersumber dari selai nanas dapat menghasilkan Rendemen sebesar 10\%. Produksi VCO tanpa menggunakan enzim bromelin juga dilakukan, dan diperoleh rendemen sebesar $8,2 \%$. Hal ini menunjukkan peningkatan produksi VCO menggunakan enzim bromelin sebesar 1,8\%.

Salah satu penyebab hilangnya stabilitas protein adalah adanya enzim. Hal ini menunjukkan bahwa protein akan mengalami denaturasi. Molekul protein yang terdenaturasi akan membuka gugus reaktif yang ada pada rantai polipeptida. kemudian akan terjadi pengikatan kembali pada gugus reaktif yang sama atau berdekatan. Bila ikatan yang terbentuk cukup banyak sehingga protein tidak terdispersi sebagai suatu koloid, maka protein mengalami koagulasi. Lapisan molekul bagian dalam protein bersifat hidrofobik berbalik keluar sedangkan bagian luar bersifat hidrofil terlipat kedalam. Hal ini menyebabkan protein mengalami koagulasi dan akhirnya akan mengalami pengendapan sehingga lapisan minyak dan air terpisah. 
Kegiatan pengabdian kepada masyarakat ini dapat memberikan edukasi, sosialisasi, motivasi dan inovasi yang berkontribusi langsung kepada masyarakat, diantaranya adalah:

1. Meningkatnya pengetahuan dan keterampilan masyarakat dalam pemanfaatan limbah pengolahan selai nanas sebagai alernatif enzim proteolitik dalam pembuatan VCO untuk kegiatan pemberdayaan kelompok UMKM "Bay Tat Mak Ririn"

2. Meningkatnya citra UNIB sebagai perguruan tinggi yang turut serta dalam penanggulangan pandemic virus corona (Covid-19) dan pemasok Teknologi Tepat Guna (TTG) untuk masyarakat sekitar, dalam hal ini masyarakat Kelurahan Kebun Kenanga, Ratu Agung, Kota Bengkulu.

3. Meningkatkan motivasi dan peluang dosen untuk menerapkan ilmu pengetahuan dan teknologi serta hasil-hasil penelitian kepada masyarakat.

Adapun faktor-faktor yang mempengaruhi pelaksanaan kegiatan pengabdian ini adalah kondisi Pandemi COVID-19. Sehingga peserta yang mengikuti kegiatan ini dibatasi hanya untuk peserta/ anggota UMKM "Bay Tat Mak Ririn" untuk menghindari kerumunan.

\section{Kesimpulan}

Dari hasil pengabdian pada UMKM "Bay Tat Mak Ririn" dapat disimpulkan bahwa:

1. Sosialisasi dan pelatihan tentang pemanfaatan limbah selai nanas dalam pembuatan VCO telah berhasil dilaksanakan oleh tim pengabdian.

2. Pengetahuan dan keterampilan para peserta setelah mengikuti kegiatan ini sangat baik. 6 orang anggota UMKM "Bay Tat Mak Ririn" telah berhasil memproduksi masing-masing $\pm 500 \mathrm{~mL}$ VCO dengan memanfaatkan limbah selai nanas sebagai sumber enzim bromelin.

\section{Pengakuan/Acknowledgements}

Ucapan trimakasih kepada LPPM Universitas Bengkulu yang telah mendanai kegiatan Pengabdian ini melalui Skim Pengabdian FMIPA tahun 2020 dengan nomor kontrak 2579/UN30.12/HK/2020. 


\section{Daftar Referensi}

Babu, A. S., Veluswamy, S. K., Arena, R., Guazzi, M., \& Lavie, C. J. (2014). Virgin Coconut Oil And Its Potential Cardioprotective Effects. Postgraduate Medicine, Clinical Focus: Thrombosis And Cardiovascular Medicine, 126(7), 76-83. Https://Doi.Org/10.3810/Pgm.2014.11.2835

Dayrit, F. M., \& Newport, M. T. (2020). The Potential Of Coconut Oil And Its Derivatives As Effective And Safe Antiviral Agents Against The Novel Coronavirus (Ncov-2019). Retrieved From I M Power Love Absolute Website: Https://I-Uv.Com/The-Potential-Of-Coconut-OilAnd-Its-Derivatives-As-Effective-And-Safe-Antiviral-Agents-AgainstThe-Novel-Coronavirus-Ncov-2019/

Ghani, N. A. A., Channip, A.-A., Hwa, P. C. H., Ja'afar, F., Yasin, H. M., \& Usman, A. (2018). Physicochemical Properties, Antioxidant Capacities , And Metal Contents Of Virgin Coconut Oil Produced By Wet And Dry Processes. Wiley Food Science \& Nutrition, 6(April), 1298-1306. Https://Doi.Org/10.1002/Fsn3.671

Karouw, S., Indrawanto, C., \& Kapu'allo, M. L. (2014). Karakteristik Virgin Coconut Oil Dengan Metode Sentrifugasi Pada Dua Tipe Kelapa. Buletin Palma, 15(2), 128-133.

Noriko, N., Masduki, A., Azhari, R., \& Nufadianti, G. (2014). Uji In Vitro Daya Anti Bakterial Virgin Coconut Oil (Vco) Pada Salmonella Typhi. Jurnal Al-Azhar Indonesia Seri Sains Dan Teknologi, 2(3), 188-192.

Oseni, N. T., Fernando, W., Coorey, R., Gold, I., \& Jayasena, V. (2017). Effect Of Extraction Techniques On The Quality Of Coconut Oil. African Journal Of Food Science, 11(March), 58-66. Https://Doi.Org/10.5897/Ajfs2016.1493

Prayitno, S. A. (2014). The Physical And Chemical Properties Of Virgin Coconut Oil (Vco) Product Obtained Through Fermentation And Enzymatic. Food Science And Technology Journal, 2(1), 1-6.

Sutanto, T. D., Martono, A., \& Ratnawati, D. (2017). Pembuatan Virgin Coconut Oil ( Vco ) Dengan Metode Tanpa Pemanasan Sebagai Upaya Meningkatkan Kesehatan Masyarakat. Jurnal Dharma Raflesia, 16(1), 55-59.

Triawan, D. A., Banon, C., \& Adfa, M. (2019). Diversification Of Coconut Products On Farmer. Jurnal Dharma Raflesia, 17(1), 34-40.

Wiyati, P. I., \& Tjitraresmi, A. (2015). Review: Karakterisasi, Aktivitas Dan Isolasi Enzim Bromelin Dari Tumbuhan Nanas (Ananas Sp.). Farmaka, 
16(2), 179-185. 